\title{
HUBUNGAN PROFIL DEMOGRAFI TERHADAP KUALITAS KINERJA PERAWAT DI RUMAH SAKIT ADVENT MANADO
}

\author{
RELATIONSHIP BETWEEN DEMOGRAPHIC PROFILE OF NURSE \\ PERFORMANCE QUALITY AT ADVENT MANADO HOSPITAL
}

Priscillia M. Saluy

Fakultas IImu Keperawatan, Universitas Klabat

E-mail:psaluy@yahoo.com

\section{ABTRAK}

Pendahuluan: Profil demografi seperti umur, status pendidikan, latar belakang pendidikan dan area kerja dapat mempengaruhi kualitas kinerja seorang perawat. Kinerja perawat melalui proses keperawatan dinilai melalui pengkajian, perencanaan, implementasi dan evaluasi. Tujuan: Tujuan penelitian ini untuk mengetahui apakah ada hubungan profil demografi terhadap kualitas kinerja perawat rumah sakit Advent Manado. Metode: Metodologi penelitian yang digunakan yaitu kuantitatif dengan desain deskriptif korelasi. Metode sampling yang digunakan yaitu purposive sampling. Sampel dalam penelitian ini berjumlah 43 responden perawat di ruangan Tulip, Aster, Jasmin dan Seruni. Hasil: Hasil penelitian ini yaitu tidak ada hubungan umur dengan kualitas kerja perawat dengan nilai signifikan $0.612>0.05$, tidak ada hubungan status pernikahan dengan kualitas kinerja perawat dengan nilai signifikan $0.636>0.05$, tidak ada hubungan latar belakang pendidikan dengan kualitas kinerja perawat dengan nilai signifikan $0.622>0.05$, ada perbedaan yang signifikan antara ruangan Aster dan Tulip. Diskusi: Kesimpulan penelitian ini tidak ada hubungan profil demografi terhadap kualitas kinerja perawat di rumah sakit Advent Manado, tetapi khusus area kerja ruangan Aster dan Tulip ada perbedaan yang signifikan.Rekomendasi bagi perawat sebagai tenaga kesehatan untuk memberikan pelayanan kepada pasien tanpa membandingkan apakah itu di area kerja ruangan bangsal, kelas ataupun VIP.

Kata kunci: profil demografi, kualitas kinerja, perawat

\begin{abstract}
Introduction: Demographic profiles such as age, educational status, educational background and work area can affect the quality of the performance of a nurse. Nurse performance assessed through the nursing process inassessment, planning, implementation and evaluation. Purpose: The purpose of this study is to determine whether a relationship exists demographic profile of the quality of nursing performance in Manado Adventist Hospital. Method: The research methodology used is quantitative descriptive correlation design. The sampling method used was purposive sampling. The sample of this study amounted to 43 respondents nurse in the room Tulip, Aster, Jasmin and Seruni. Results: The results of this research that there is no relationship with the quality of work life of nurses with significant value $0612>0.05$, there was no association of marital status with quality of performance of nurses with a significant value of $0.636>0.05$, no relation to the quality of the educational background of nurses with significant value $0622>0.05$, there is a significant difference between the room Aster and Tulip. Discussion: In conclusion, there is no relationship to the quality of the demographic profile of nurses in Manado Adventist Hospital, but specific work area Aster and Tulip room there is a significant difference. Recommendations for nurses as health professionals to provide care to patients without comparing whether it is in the ward -room work area, classes room, or VIP class.
\end{abstract}

JURNAL

SKOLASTIK

KEPERAWATAN

Vol, 4, No. 2

Juli - Desember 2018

ISSN: $2443-0935$

E-ISSN 2443 - 16990 
Keywords: demographic profile, quality of performance, nurses

\section{PENDAHULUAN}

Menjelang era pasar bebas atau dikenal AFTA (Asean FreeTrade Assosiation) diperlukan kesiapan yang mantap dari semua sektor, termasuk sektor kesehatan khususnya rumah sakit. Berbagai upaya telah dilakukan untuk meningkatkan kualitas pelayanan rumah sakit, diantaranya adalah akreditasi rumah sakit yang ada saat ini mulai dituntut oleh masyarakat pengguna jasa pelayanan rumah sakit (Departemen Kesehatan RI dalam Natsir dan Joeharno, 2008).

Keperawatan adalah suatu bentuk pelayanan yang merupakan bagian integral dari pelayanan kesehatan berdasarkan ilmu dan kiat keperawatan, bentuk pelayanan bio-psiko-sosiospiritual yang komprehensif, ditujukan kepada individu, keluarga, dan masyarakat baik sakit maupun sehat yang mencakup seluruh kehidupan manusia (Sitorus dalam Randa, 2011).

Asuhan keperawatan berkualitas adalah pertimbangan utama dari semua perawat.Kinerja menjadi tolak ukur keberhasilan pelayanan keperawatan.Kinerja perawat mengacu pada tingkah laku saat memberikan pelayanan / asuhan keperawatan kepada pasien.Melalui kinerja perawat diharapkan dapat menunjukkan kontribusi profesionalnya secara nyata dalam meningkatkan mutu pelayanan keperawatan, yang berdampak terhadap pelayanan kesehatan secara umum pada organisasi tempatnya bekerja, dan dampak akhir bermuara pada kualitas hidup dan kesejahteraan masyarakat (Heru dalam Randa, 2011).

Menurut Gibson yang dikutip oleh Randa (2011), kinerja dipengaruhi oleh beberapa faktor, yaitu karakterisitik individu (umur, pengalaman kerja, status perkawinan, tingkat pendidikan), organisasi

(kompensasi, pengembangan karir, sumber daya, kebijakan organisasi dan iklim kerja), dan keluarga.

Beberapa penelitian di AS menunjukkan 60-70\% dari pekerja shift mengeluh kesulitan tidur atau masalah dalam kantuk. Studi lain lokal dengan Refere dan Jorge, 2005 menunjukkan bahwa $90 \%$ di antara penduduk medis di Rumah Sakit Umum Filipina yang memiliki shift kerja atau pergi bertugas selama 24 jam memiliki kantuk di siang hari yang berlebihan. Ini akan mempengaruhi suasana hati dan kinerja produktivitas.

Rumah Sakit Advent Manado mempunyai tiga shift atau waktu dinas, yaitu dinas pagi jam 7 pagi sampai jam 3 sore, dinas siang jam 3 sore sampai jam 11 malam dan dinas malam jam 11 malam sampai jam 7 pagi. Data awal yang diambil pada bulan Juli menunjukkan ruangan Tulip memiliki 10 kamar utama/VIP dengan 16 tenaga perawat, ruangan Aster memiliki kapasitas 30 tempat tidur pasien dengan 18 tenaga perawat, ruangan Jasmine memiliki 31 tempat tidur pasien dengan 17 tenaga perawat dan ruangan Seruni memiliki 20 tempat tidur dengan 19 tenaga perawat. 


\section{BAHAN DAN METODE}

Penelitian ini adalah kuantitatif dengan desain deskriptif korelasi, dimana umur, status pernikahan, tingkat pendidikan dan area kerja merupakan variable independent dihubungkan dengan kualitas kinerja perawat yang menjadi variable dependent.

Teknik sampling yang digunakan dalam penelitian ini yaitu purposif sampling, Dalam penelitian ini sampel diperoleh dari populasi perawat yang berada di empat ruangan rumah sakit Adven Manado.Peneliti mendapat 43 sampel yang bersedia menjadi responden dari total populasi 70 orang. yaitu semua perawat yang bekerja di ruangan bangsal, kelas dan VIP seperti Tulip, Aster, Jasmin dan Seruni. Umur antara 22 tahun sampai 40 tahun.Status menikah dan belum menikah.Memiliki jenjang pendidikan D3 dan S1 keperawatan. Bersedia menjadi responden dan menandatangani surat persetujuan (informed consent). Total responden yaitu 43 perawat. Batasan dalam penelitian ini yaitu perawat yang tidak dalam masa percobaan, sedang cuti hamil dan tidak bersedia menjadi responden. Adapun metode pengumpulan data yang digunakan dalam penelitian ini berupa kuesioner.

HASIL

Tabel 1. Data umur responden

\begin{tabular}{lllll}
\hline & & \multicolumn{2}{l}{ PENDIDIKAN } & Total \\
& & D3 & S1 & \\
\hline UMUR & $\begin{array}{l}22-29 \\
\text { thn }\end{array}$ & 6 & 26 & 32 \\
& $30-40$ & 5 & 6 & 11 \\
Total & & 11 & 32 & 43 \\
\hline
\end{tabular}

Tabel 1. menunjukkan berdasarkan umur responden yang berusia 22-29 tahun memiliki 6 orang dengan tingkat pendidikan D3 sedangkan S1 26 orang dan umur 30-40 tahun memiliki 5 orang dengan tingkat pendidikan D3 sedangkan S1 6 orang, jumlah responden 43 orang.

Tabel 2. Data status pernikahan responden

\begin{tabular}{lllll}
\hline \multirow{2}{*}{ UMUR } & & \multicolumn{2}{l}{$\begin{array}{l}\text { STATUS } \\
\text { Single }\end{array}$} & Total \\
\cline { 3 - 4 } & $\begin{array}{l}22-29 \\
\text { thn }\end{array}$ & 23 & 9 & 32 \\
\multirow{2}{*}{ Total } & $30-40$ & 4 & 7 & 11 \\
& & 27 & 16 & 43 \\
\hline
\end{tabular}

Tabel 2. menunjukkan berdasarkan umur responden 22-29 tahun yang berstatus single 23 orang sedangkan 9 orang sudah menikah dan umur 30-40 tahun ada 4 orang yang berstatus single sedangkan 7 orang sudah menikah, jumlah responden 43 orang.

Tabel 3. Data latar belakang responden

\begin{tabular}{lllll}
\hline & & \multicolumn{2}{l}{ STATUS } & Total \\
& & single & married & \\
\cline { 3 - 4 } PENDIDIK & D3 & 7 & 4 & 11 \\
& S1 & 20 & 12 & 32 \\
Total & & 27 & 16 & 43 \\
\hline
\end{tabular}

Tabel 3. menunjukkan latar belakang pendidikan D3 yang berstatus single 7 orang sedangkan yang menikah 4 orang dan latar belakang pendidikan S1 yang masih single 20 orang sedangkan yang menikah 12 orang, jumlah responden 43 orang. 
Tabel 4. Analisa hubungan umur dengan kualitas kinerja perawat berdasarkan uji statistik

pearson correlation

\begin{tabular}{llll}
\hline & & UMUR & KINERJA \\
\hline UMUR & $\begin{array}{l}\text { Pearson } \\
\text { Correlation }\end{array}$ & 1 & -.080 \\
& $\begin{array}{l}\text { Sig. } \quad(2- \\
\text { tailed) }\end{array}$ &. & .612 \\
& $\mathrm{~N}$ & 43 & 43 \\
KINERJA & $\begin{array}{l}\text { Pearson } \\
\text { Correlation }\end{array}$ & -.080 & 1 \\
& $\begin{array}{l}\text { Sig. (2- } \\
\text { tailed) }\end{array}$ & .612 &. \\
& $\mathrm{~N}$ & 43 & 43 \\
\hline
\end{tabular}

Tabel 4. menunjukkan hasil analisa ada hubungan umur dengan kualitas kinerja perawat dengan nilai signifikan $0.612>0.05$. Dengan demikian Ho1: Tidak ada hubungan umur dengan kualitas kinerja perawat rumah sakit Advent Manado, diterima.

Hal ini tidak sesuai dengan tulisan Robbins dalam Nusawakan (2006) yang menyatakan bahwa pekerja yang lebih tua membawa pekerjaan mereka secara khusus, pengalaman, penilaian, etos kerja yang kuat dan komitmen terhadap kualitas. Setiap penurunan keterampilan fisik karena usia berdampak pada produktivitas, jika ada beberapa penurunan karena usia, itu diimbangi oleh keuntungan karena pengalaman.

Asumsi yang peneliti bisa ambil adalah perawat di rumah sakit Advent Manado baik usia antara 22-29 tahun dan usia antara 30-40 tahun memiliki kualitas kinerja yang sama, karenaperawat yang masih muda, freshgraduate memiliki semangat yang besar untuk melayani pasien sedangkan perawat yang lebih tua unggul dalam pengalaman melayani sehingga hasil kinerjanya berimbang antara yang muda dan yang sudah berpengalaman.

Untuk menjawab hipotesa kedua dengan Ho2: Tidak ada hubungan status pernikahan dengan kualitas kinerja perawat di rumah sakit Advent Manado maka peneliti menggunakan rumus spearman correlation

Tabel 5. Analisa hubungan status pernikahan dengan kualitas kinerja perawat berdasarkan uji statistik spearman correlation

\begin{tabular}{|c|c|c|c|c|}
\hline & & & KINERJA & STATUS \\
\hline \multirow[t]{6}{*}{ Spearman's rho } & KINERJA & Correlation Coefficient & 1.000 & .097 \\
\hline & & Sig. (2-tailed) & . & .536 \\
\hline & & $\mathrm{N}$ & 43 & 43 \\
\hline & STATUS & Correlation Coefficient & .097 & 1.000 \\
\hline & & Sig. (2-tailed) & .536 & . \\
\hline & & $\mathrm{N}$ & 43 & 43 \\
\hline
\end{tabular}

Tabel 5. menunjukkan hasil analisa ada hubungan status pernikahan dengan kualitas kinerja perawat dengan nilai signifikan $0.536>0.05$. Dengan demikian Ho2: Tidak ada hubungan status pernikahan dengan kualitas kinerja perawat rumah sakit Advent Manado, diterima.

Hal ini tidak sesuai dengan tulisan Robbins dalam Nusawakan (2006) yang menyatakan bahwa karyawan yang sudah menikah memiliki lebih 
sedikit absen, mengalami pergantian lebih sedikit dan lebih puas dengan pekerjaan mereka daripada rekan kerja mereka yang belum menikah.

Asumsi yang peneliti dapatkan mengapa tidak signifikan hubungan status pernikahan dengan kualitas kinerja, karena perawat yang sudah menikah dan yang belum menikah bekerja melayani pasien di rumah sakit swasta yang menuntut karyawannya mempunyai kulitas kinerja yang
tinggi.Perawat juga dinilai oleh atasan/supervisor sekali dalam tiga bulan sehingga perawat terpacu untuk memberikan kualitas kinerja yang terbaik.

Untuk menjawab hipotesa ketiga dengan $\mathrm{Ho}_{3}$ : Tidak ada hubungan latar belakang pendidikan dengan kualitas kinerja perawat rumah sakit Advent Manado, peneliti menggunakan rumus pearson correlation.

Tabel 6. Analisa hubungan latar belakang pendidikan dengan kualitas kinerja perawat berdasarkan uji statistik pearson correlation

\begin{tabular}{llll}
\hline & & KINERJA & PENDIDIK \\
\hline KINERJA & Pearson Correlation & 1 & -.077 \\
& Sig. (2-tailed) &. & .622 \\
PENDIDIK & $\mathrm{N}$ & 43 & 43 \\
& Pearson Correlation & -.077 & 1 \\
& Sig. (2-tailed) & .622 &. \\
$\mathrm{~N}$ & 43 & 43 \\
\hline
\end{tabular}

Tabel 6. menunjukkan hasil analisa ada hubungan latar belakang pendidikan dengan kualitas kinerja perawat dengan nilai signifikan 0.622 $>0.05$. Dengan demikian Ho1: Tidak ada hubungan latar belakang pendidikan dengan kualitas kinerja perawat rumah sakit Advent Manado, diterima.

Hal ini tidak sesuai dengan penelitian yang dilakukan oleh Aiken (2003) yang menemukan hubungan yang jelas antara tingkat pendidikan keperawatan

yang lebih tinggi dan hasil pasien yang lebih baik. Studi ekstensif menemukan bahwa pasien bedah memiliki "manfaat kelangsungan hidup yang besar" jika dirawat di rumah sakit dengan proporsi perawat sarjana muda atau tingkat yang lebih tinggi. Di rumah sakit, peningkatan 10 persen dalam proporsi perawat memegang gelar BSN menurunkan risiko kematian pasien dan kegagalan untuk menyelamatkan sebesar 5 persen.

Asumsi yang peneliti bisa ambil mengapa sampai tidak signifikan hasil yang didapat, karena rumah sakit swasta mempunyai tuntutan yang tinggi terhadap kinerja perawat sebagai karyawan. Produktivitas perawat di nilai secara continue 
sehingga perawat sebagai karyawan lebih terpacu untuk memberikan asuhan keperawatan yang tepat.

Untuk menjawab hipotesa keempat dengan Ho4: Tidak ada perbedaan yang signifikan kualitas kinerja perawat rumah sakit Advent Manado berdasarkan area kerja, peneliti menggunakan rumus Duncan.

Tabel 7. Analisa perbedaan kualitas kinerja perawat berdasarkan area kerja ruangan menggunakan uji bedaDuncan

\begin{tabular}{llll}
\hline RUANGAN & $\mathrm{N}$ & \multicolumn{2}{l}{ Subset for alpha $=.05$} \\
\cline { 3 - 4 } & & 1 & 2 \\
Aster & 10 & 4.1875 & \\
Seruni & 13 & 4.3865 & 4.3865 \\
Jasmin & 12 & 4.4104 & 4.4104 \\
Tulip & 8 & & 4.5781 \\
Sig. & & .202 & .272 \\
\hline
\end{tabular}

Tabel 7. menunjukkan hasil analisa ada perbedaan yang signifikan kualitas kinerja perawat berdasarkan area kerja ruangan Aster, Seruni, Jasmin tidak berbeda dengan nilai signifikan 0.202 $>$ 0.05. Ruangan Seruni, Jasmin, Tulip tidak berbeda dengan nilai signifikan $0.272>0.05$. Perbedaan yang sigifikan terjadi antara Aster dan Tulip, sedangkan yang lainnya tidak berbeda. Dengan demikian Ho4: Tidak ada perbedaan yang signifikan kualitas kinerja perawat rumah sakit Advent Manado berdasarkan area kerja ruangan, ditolak.

Kesimpulan yang peneliti dapatkan, ruangan Tulip adalah kelas VIP dimana tuntutan pasien lebih tinggi dibandingkan dengan di ruangan bangsal.Perawat dituntut untuk memberikan pelayanan yang maksimal sehingga kualitas kinerja mereka lebih dipacu untuk lebih baik lagi hari demi hari. Perbandingan kapasitas tempat tidur dengan perawat
10:16, dimana bed capacity 10 dan tenaga perawat 16. Aster adalah ruangan kelas 2 dan 3 (bangsal) dengan perbandingan 30 bed capacity dan 18 tenaga perawat. Hal ini dapat menurunkan kualitas kinerja khususnya di ruangan Aster karena faktor kelelahan.Kelelahan bisa menjadi faktor turunnya kualitas kinerja seorang perawat.Kelelahan kerja menunjukan keadaan yang berbeda-beda tetapi semuanya berkaitan kepada pengurangan kapasitas kerja dan ketahanan umum (Wijaya \& Setyawati. 2006).

Kinerja kurang juga dapat disebabkan karena adanya unsur dari luar diri tenaga perawat yang mempengaruhi psikologis sehingga menurunkan semangat kerja dalam rangka pemenuhan pelayanan keperawatan di rumah sakit. Aspek yang berasal dari luar ini mencakup hubungan interpersonal dengan teman sejawat di tempat kerja, adanya konflik internal 
keorganisasiaan rumah sakit, kurangnya aspek motorik dari rumah sakit dalam rangka pemberian motivasi kepada tenaga perawat sehingga dapat melaksanakan tindakan asuhan keperawatan yang lebih berkualitas dan menjawab tuntutan masyarakat akan kebutuhan pelayanan (Natsir \& Joeharno, 2008).

\section{KESEIMPULAN}

1. Setelah dilakukan penelitian hubungan profil demografi terhadap kualitas kinerja perawat rumah sakit Advent Manado, maka dapat diambil kesimpulan bahwa tidak ada hubungan profil demografi yaitu umur, status pernikahan, latar belakang pendidikan dan area kerja dengan kualitas kinerja perawat rumah sakit Advent Manado dengan memakai rumus pearson correlation dan spearman correlation. Bila memakai rumus uji bedaDuncan maka terlihat jelas bahwa perawat di area kerja ruangan Tulip lebih tinggi kualitas kinerja dibandingkan dengan ruangan lain seperti Jasmin, Seruni dan Aster.

2. Masukkan kepada para perawat sebagai tenaga kesehatan untuk memberikan pelayanan kepada pasien tanpa membandingkan apakah itu di area kerja ruangan bangsal, kelas ataupun VIP. Berikan kualitas kinerja yang sama tingginya. Usaha ataupun upaya maksimal yang perawat berikan kepada pasien akan memberikan nilai yang tinggi juga. Holistic care ditingkatkan untuk peningkatan mutu pelayanan dan perawatan, lebih berinisiatif dalam bekerja, lebih sabar dan efisien.Selain itu perawat perbanyak waktu dengan pasien agar mengetahui kebutuhan pasien secara keseluruhan khususnya di ruangan kelas ataupun bangsal.

3. Pihak rumah sakit dapat melengkapi peralatan/fasilitas di ruang perawatan guna peningkatan kualitas kinerja perawat. Lebih memberikan motivasi kepada perawat sebagai karyawan, hindari konflik internal keorganisasian rumah sakit sehingga perawat dapat melaksanakan tindakan asuhan keperawatan yang lebih berkualitas dan menjawab tuntutan masyarakat akan kebutuhan pelayanan .

4. Selama periode pendidikan formal, mahasiswa perawat dapat belajar dan memperoleh pengalaman yang berharga mengenai kualitas kinerja perawat dimana proses keperawatan yaitu pengkajian, perencanaan, implementasi dan evaluasi akan dialami. Mahasiswa keperawatan dipersiapkan untuk mengambil peran yang aktif sebagai pelaksanan profesional di keadaan kerja masa yang akan datang.

5. Penelitian yang sama dapat dilakukan di rumah sakit yang populasi tenaga keperawatan lebih besar. Dapat juga ditambahkan kinerja yang dipengaruhi oleh agama/kepercayaan, budaya, lama dinas, kemampuan, motivasi dan pembawaan.

\section{DAFTAR PUSTAKA}

Aiken, L.H., Clarke, S.P., Cheung, R.B., Sloane,D.M., \& Silber, J.H. (2003， 24 September). 
Educational levels of hospital nurses and surgical patient mortality. Journal of the American Medical Association. 290, 1617-1623.

Arikunto, S. (2003). Prosedur Penelitian, Edisi Revisi V. Jakarta: Rineka Cipta

Jansen. (2006). Journal of the royal statistical society. University of Hawai, 147:158

Natsir, Erlin. SKM \& Joeharno, SKM. (2008). Kinerja perawat dalam melaksanakan asuhan keperawatan di rumah sakit dan faktor yang mempengaruhinya. (Skripsi)

Nusawakan, Mary. (2006). Working climate and quality performance of staff nurses in the various nursing units of
Bandung Adventist hospital. (Thesis)

Randa. (2011). Hubungan komponen kualitas kehidupan kerja dengan kinerja perawat pelaksanan di instalasi rawat inap bedah dan non bedah RSUP. DR. $M$. DJAMIL PADANG. (Thesis)

Refere G, Jorge M. (2005). Sleeping Patterns of Resident and Training at the UP-PGH as Measured by the Epworth Sleepiness Scale; Phil J Int Med; 43:241).

Setyawati L.M. \& Wijaya, Endang S, (2006). Hubungan Shift Kerja Dengan Gangguan Tidur Dan Kelelahan Kerja Perawat Instalasi Rawat Darurat RS DR. Sardjito Yogyakarta, Sains Kesehatan, vol 19(2). Pp. 235245 